\title{
The Assessment of Climate Change Impact on Meteorological Draught Susceptability on Sampean Watershed
}

\author{
(Asesmen Dampak Perubahan Iklim Terhadap Kerentanan Bencana Kekeringan \\ Meterorologis di Das Sampean)
}

Masita Ratih, Gusfan Halik*), Retno Utami Agung Wiyono

Jurusan Teknik Sipil, Fakultas Teknik, Universitas Jember

Jn. Kalimantan 37, Jember 68121

\section{ABSTRACT}

Drought disasters that occur in the Sampean watershed from time to time have increased, both the intensity of events and the area affected by drought. The general objective of this research is to develop an assessment method for the impact of climate chan ge on vulnerability to drought disasters based on atmospheric circulation data. The specific objectives of this study are to model rainfall predictions based on atmospheric circulation data, predict rainfall in various climate change scenarios (Intergovernm ental Panel on Climate Change, IPCC - AR5), and assess vulnerability to drought disasters using a meteorological approach. The Standardized Precipitation Index (SPI) is one way to analyze the drought index in an area which was developed previous researcher. The Standardized Precipitation Index (SPI) is designed to quantitatively determine the rainfall deficit with various time scales. The advantage of the Standardized Precipitation Index (SPI) is that it is enough to use monthly rainfall data to compare drou ght levels between regions even with different climate types. To facilitate the presentation of the data base on the identification of $\mathrm{d}$ rought susceptibility, we need a system that can assist in building, storing, managing and displaying geographically ref erenced information in the form of spatial mapping. This research facilitates monitoring of the area of drought-prone areas, predicts drought levels, prevents future drought disasters, and prepares plans for rebuilding drought-prone areas in the Sampean watershed.

Bencana kekeringan yang terjadi di DAS Sampean dari waktu ke waktu mengalami peningkatan, baik intensitas kejadian maupun luasan daerah yang terdampak kekeringan. Tujuan umum penelitian ini adalah mengembangankan metode asesmen dampak perubahan iklim terhadap kerentanan bencana kekeringan berbasis data sirkulasi atmosfir. Tujuan khusus penelitian ini adalah memodelkan prediksi curah hujan berdasarkan data sirkulasi atmosfir, memprediksi curah hujan pada berbagai skenario perubahan iklim (Intergovernmental Panel on Climate Change, IPCC - AR5), dan asesmen tingkat kerentanan bencana kekeringan dengan pendekatan meteorologis. Standardized Precipitation Index (SPI) adalah salah satu cara dalam menganalisis indeks kekeringan pada suatu daerah yang di kembangkan sebelumnya. Standardized Precipitation Index (SPI) didesain untuk mengetahui secara kuantitatif defisit hujan dengan berbagai skala waktu. Keunggulan Standardized Precipitation Index (SPI) adalah cukup menggunakan data curah hujan bulanan untuk membandingkan tingkat kekeringan antar wilayah meskipun dengan jenis iklim yang berbeda. Untuk mempermudah penyajian data base hasil identifikasi kerentanan kekeringan, diperlukan suatu sistem yang dapat membantu dalam membangun, menyimpan, mengelola serta menampilkan informasi berefrensi geografis dalam bentuk pemetaan spasial. Penilitian ini memudahkan pemantauan terhadap luas wilayah kawasan rawan kekeringan, memprediksi tingkat kekeringan, mencegah terjadinya bencana kekeringan pada masa datang, serta menyusun rencana-rencana pembangunan kembali kawasan rawan kekeringan di DAS Sampean.

Keywords: Perubahan Iklim, SPI, Downscaling, ANN, RCP. 


\section{PENDAHULUAN}

Perubahan iklim terjadi akibat adanya pemanasan global yang disebabkan oleh peningkatan konsentrasi gas rumah kaca. Salah satu gas rumah kaca yang memiliki andil besar terhadap perubahan iklim adalah gas CO. Perubahan iklim akan memberikan pengaruh terhadap jumlah, intensitas, pola hujan, dan kejadian hujan ekstrim (banjir dan kekeringan) (Anwar et al., 2014). Kekeringan (drought) merupakan suatu kejadian alam yang ditunjukkan dengan terbatasnya ketersediaan cadangan air di atas, di permukaan, dan di dalam tanah, baik untuk kegiatan pertanian maupun untuk kebutuhan manusia (Saidah et al., 2017). Kekeringan berasal dari kurangnya curah hujan yang turun dan atau ketidak cukupan curah hujan yang turun pada suatu periode tertentu (Nurrahman \& Pamungkas, 2013). Bencana kekeringan memiliki karakteristik yang unik, karena terjadi secara perlahan dan sulit untuk diprediksi kapan awal mula terjadinya. Keunikan karakteristik ini yang menyebabkan kekeringan sulit untuk diukur secara pasti (Anwar et al., 2014). Informasi mengenai iklim pada saat ini dan proyeksi iklim di masa yang akan datang merupakan suatu bentuk mitigasi terhadap risiko kegagalan panen akibat perubahan iklim. Sehingga, diperlukan suatu prediksi terhadap perubahan iklim di masa yang akan datang (Kusumawati et al., 2020).

Berdasarkan data yang terdapat pada situs Bappenas, Kabupaten Bondowoso yang wilayahnya merupakan sebagian besar dari DAS Sampean akan mengalami satu bulan defisit air selama satu tahun mulai dari tahun 2015 hingga dua puluh tahun mendatang. Diperkuat dengan pernyataan dari Balai Pengelolaan Wilayah Sungai Sampean Baru yang menempatkan kekeringan merupakan isu pokok, dengan indikator Indeks Penggunaan Air (IPA) $>1$ masuk dalam kategori buruk (Sari et al., 2012). Berdasarkan kondisi tersebut, perlu dilakukan langkah awal untuk mitigasi bencana kekeringan dengan cara memantau dan menganalisis kekeringan meteorologis di DAS Sampean. lain:

Tujuan dari penentuan tingkat kekeringan, antara 1. Mengevaluasi tingkat kekeringan lahan, serta kecenderungan klimatologis menuju keadaan kering. 2. Memprediksi kebutuhan air irigasi pada suatu daerah.
3. Mengevaluasi kekeringan pada suatu tempat secara lokal.

4. Mengamati perkembangan kekeringan regional secara berkala. (Sinta Afdeni, Sigit Sutikno, 2017)

Upaya untuk memantau dan menganalisis kekeringan dapat dilakukan dengan menggunakan indeks kekeringan. WMO (World Meteorological Organization) (2012) sebagai suatu Badan Meteorologi Dunia menganjurkan kepada semua badan meteorologi dan hidrologi nasional untuk menggunakan metode SPI (Standardized Precipitation Index) dalam memonitor tingkat kekeringan. SPI merupakan indeks kekeringan yang memiliki beberapa karakteristik dan merupakan peningkatan dari indeks sebelumnya, antara lain kesederhanaan dan fleksibilitas temporal yang memungkinkan penerapannya dalam sumber daya air pada semua skala waktu (Hayes et al., 1999). Selain itu, SPI memiliki beberapa kelebihan, diantaranya cukup menggunakan data curah hujan bulanan, dapat digunakan untuk membandingkan tingkat kekeringan antar wilayah meskipun dengan jenis iklim yang berbeda.

Perhitungan nilai SPI berdasarkan jumlah sebaran gamma yang didefinisikan sebagai fungsi frekuensi atau peluang kejadian sebagai berikut (Teja et al., 2017).

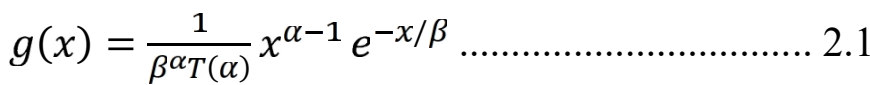

Nilai $\alpha$ dan $\beta$ diestimasi untuk setiap stasiun hujan dengan menggunakan rumus sebagai berikut:

$\alpha=\frac{1}{4\left(\operatorname{ll}(\widetilde{\mathrm{x}})\left(\frac{\Sigma \mathrm{l} !(x)}{n}\right)\right.}\left(1+\sqrt{\frac{1+4\left(\ln (\widetilde{\mathrm{x}})-\frac{\Sigma \ln (\mathrm{x})}{\mathrm{n}}\right.}{3}}\right) 2.2$

Atau,

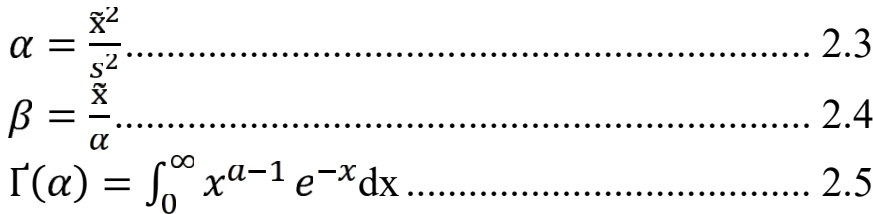

Dimana :

$g(x) \quad$ : fungsi dari sebaran gamma,

$x \quad$ : jumlah curah hujan ( $\mathrm{mm} /$ bulan),

$\Gamma(\alpha) \quad$ : fungsi gamma,

e : eksponensial,

a : parameter shape $(\alpha>0)$,

$\beta \quad$ : parameter skala $(\beta>0)$,

$n \quad$ : jumlah data hujan yang diobservasi,

dan 
$x$ : rata-rata curah hujan.

Parameter yang dihasilkan kemudian digunakan untuk mengetahui kemungkinan kumulatif selama rentang waktu penelitian. Kemungkinan rentang kumulatif $G(x)$ dihitung dengan menggunakan persamaan :

$G(x)=\int_{0}^{x} g(x) d=\frac{1}{\beta^{\alpha} \Gamma(a)} \int_{0}^{x} x^{a-1} e^{-\frac{x}{\beta}} d \quad \ldots . .2 .6$

Dimana $\mathrm{t}=\frac{x}{\beta}$, fungsi gamma dapat ditulis secara lengkap dengan:

$G(x)=\frac{1}{\ulcorner(\alpha)} \int_{0}^{t} t^{a-1} e^{-t} d$

Fungsi gamma tidak terdefinisi bila $x=0$ dan distribusi curah hujan bisa berisi angka nol, maka kemungkinan kumulatif dapat dihitung dengan menggunakan persamaan :

$\mathrm{H}(x)=\mathrm{q}+(1-\mathrm{q}) \mathrm{G} x$

Dimana $q$ merupakan kemungkinan kejadian tanpa hujan. Jika $m$ adalah jumlah bulan tanpa kejadian hujan selama rentang waktu penelitian, maka $q$ dapat diestimasi dengan $m / n$. Kemungkinan kumulatif $\mathrm{H}(x)$ kemudian ditransformasikan ke standar normal acak variabel $Z$ dengan rata-rata nol dengan varian satu, yang didefinisikan sebai nilai SPI.

$$
Z=S=-\left(t-\frac{c_{0}+c_{1} t+c_{2} t^{2}}{1+d_{1} t+d_{2} t^{2}+d_{3} t^{3}}\right)
$$

untuk $0<\mathrm{H}(\mathrm{x}) \leq 0,5$

$Z=S=+\left(t-\frac{c_{0}+c_{1} t+c_{2} t^{2}}{1+d_{1} t+d_{2} t^{2}+d_{3} t^{3}}\right)$

untuk $0,5<\mathrm{H}(\mathrm{x}) \leq 1,0$ dengan,

$t=\sqrt{\ln \left(\frac{1}{(H(x))^{2}}\right)} 2.11$

untuk $0<\mathrm{H}(\mathrm{x}) \leq 0,5$

$t=\sqrt{\operatorname{ll}\left(\frac{1}{(1.0-H(x))^{2}}\right)} \quad 2.12$

untuk $0,5<\mathrm{H}(\mathrm{x}) \leq 1,0$ dengan,

$\mathrm{c}_{0}=2,515517$

$\mathrm{c}_{1}=0,802853$

$\mathrm{c}_{2}=0,010328$

$\mathrm{d}_{1}=1,432788$

$\mathrm{d}_{2}=0,189269$

$\mathrm{d}_{3}=0,001308$
Kekeringan terjadi pada waktu SPI secara berkesinambungan negatif dan mencapai intensitas kekeringan dengan SPI bernilai -1 atau lebih kecil.

Nilai SPI positif menunjukkan curah hujan yang diperoleh lebih besar dari curah hujan rata-rata, sedangkan nilai negatif menunjukkan curah hujan yang diperoleh lebih kecil dari curah hujan ratarata. Metode SPI dapat dipresentasikan pada iklim normal, basah, dan kering dengan cara yang sama. Menurut McKee, 1993, nilai-nilai untuk klasifikasi SPI dapat dikategorikan sebagai berikut:

$\begin{array}{ll}\text { Sangat Basah } & : \geq 2 \\ \text { Basah } & : 1,50 \mathrm{~s} / \mathrm{d} 1,99 \\ \text { Agak Basah : 1,00 s/d 1,49 } & \\ \text { Normal } & :-0,99 \mathrm{~s} / \mathrm{d} 0,99 \\ \text { Agak Kering } & :-1,00 \mathrm{~s} / \mathrm{d}-1,49 \\ \text { Kering } & :-1,50 \mathrm{~s} / \mathrm{d}-1,99 \\ \text { Sangat Kering } & : \leq-2\end{array}$

Untuk mempermudah dalam penyajian data base hasil identifikasi kerentanan kekeringan, diperlukan suatu sistem yang dapat membantu dalam membangun, menyimpan, mengelola serta menampilkan informasi berefrensi geografis dalam bentuk pemetaan spasial. Dengan adanya pemetaan spasial ini, diharapkan akan lebih mudah dalam memantau luas wilayah kawasan rawan kekeringan, memprediksi tingkat kekeringan, mencegah terjadinya bencana kekeringan pada masa datang, serta menyusun rencana-rencana pembangunan kembali kawasan rawan kekeringan.

Salah satu pendekatan untuk memprediksi curah hujan di masa yang akan dating adalah dengan memanfaatkan Data Luaran Global Circulation Model (GCM). Namun, informasi dari Data Luaran GCM masih berskala global, sehingga sulit untuk mendapatkan langsung informasi untuk fenomena yang lebih kecil (berskala lokal) dari GCM. Meskipun demikian, GCM masih mungkin digunakan untuk mendapatkan informasi berskala lokal melalui Teknik Downscaling (Wigena, Aji Hamim, Anik Djuraidah, 2017).

Dalam penelitian ini dilakukan perhitungan terhadap indeks kekeringan menggunakan data lapangan dan data luaran satelit NOAA. Hasil perhitungan kedua data tersebut dikorelasi untuk mengetahui hubungan antara keduanya. Kriteria korelasi tersaji dalam tabel 1 berikut: 
Tabel 1. Kriteria Korelasi

\begin{tabular}{cc}
\hline Nilai Koefisien Korelasi & Kriteria Korelasi \\
\hline $0-0,25$ & Korelasi sangat lemah \\
$>0,25-0,5$ & Korelasi cukup \\
$>0,5-0,75$ & Korelasi kuat \\
$>0,75-1$ & Korelasi sangat kuat \\
\hline
\end{tabular}

(Ardika Sulaeman, 2014)

Skenario RCP menggantikan skenario emisi (SRES) yang diterbitkan pada tahun 2000. Skenario RCP dikeluarkan dalam Laporan Penilaian Ke-5 (AR5) tahun 2014. Apabila dibandingkan dengan skenario emisi (SRES), skenario RCP lebih dapat memproyeksikan perubahan iklim di masa mendatang, karena telah dilengkapi dengan skenario berdasarkan faktor-faktor meliputi populasi, aktivitas ekonomi, gaya hidup, penggunaan energi, dan pola penggunaan lahan. Dalam penelitian ini, dilakukan prediksi kekeringan di masa yang akan datang dengan skenario RCP 8.5. Skenario RCP 8.5 menggambarkan kondisi paling ekstrim diantara scenario yang lain, yaitu dengan tingkat $\mathrm{CO}_{2}$ lebih dari 1200 ppm dan peningkatan temperatur global hingga $4,8^{\circ} \mathrm{C}$ pada tahun 2100. Penelitian ini bertujuan untuk mengidentifikasi kerentanan kekeringan, asesmen bencana kekeringan meteorologis pada berbagai skenario perubahan iklim yang terjadi, serta pemetaan spasial kerentanan kekeringan di DAS Sampean.

\section{METODE PENELITIAN}

\section{Lokasi Penelitian}

Kabupaten Bondowoso, adalah sebuah kabupaten di Provinsi Jawa Timur yang merupakan satu-satunya kabupaten yang tidak memiliki wilayah laut (terkurung daratan) di wilayah Tapal Kuda, Jawa Timur. Kabupaten Bondowoso memiliki luas wilayah $1.560,10 \mathrm{~km} 2$ yang secara geografis berada pada koordinat antara $113^{\circ} 48^{\prime} 10^{\prime \prime}$ - 113 $48^{\prime} 26^{\prime \prime}$ BT dan 750'10" - 756'41" LS.

Luas kawasan rawan bencana kekeringan di Kabupaten Bondowoso seluruhnya adalah 20.934 Ha, sementara kawasan yang memiliki potensi bencana kekeringan seluas 126.971 Ha. Kawasan yang mengalami bencana kekeringan ini kesulitan untuk mendapatkan suplai air baik untuk kebutuhan seharihari maupun lainnya. Lokasi penelitian ditunjukkan pada Gambar 1.

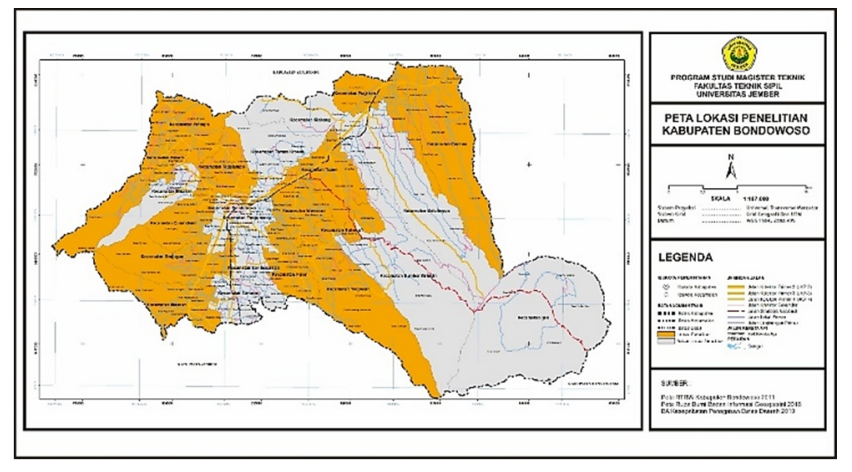

Gambar 1. Lokasi Penelitian

\section{Pengumpulan Data}

Data yang digunakan dalam penelitian ini adalah :

1) Data curah hujan bulanan tahun 1988-2018 (30 tahun) yang diperoleh dari UPT PSAWS Sampean Stail.

2) Data kegagalan panen akibat kekeringan yang diperoleh dari UPT LPHPPTH Tanggul-Jember.

3) Peta Dasar GIS Kabupaten Bondowoso (Peta RTRW) yang diperoleh dari BAPPEDA Kabupaten Bondowoso.

4) Data luaran GCM dan data satelit NOAA (NCEP/NCAR reanalysis).

5) GHG emission pathways 2000-2100: All AR5 scenarios.

Data dapat dikatakan valid jika memenuhi beberapa kriteria (Soemarto, 1987), yaitu bahwa data itu berada dalam range, tidak mempunyai trend, homogen dan bersifat acak. Pada studi ini analisis hidrologi yang digunakan adalah:

1) Uji konsistensi yang berfungsi untuk melihat apakah data curah hujan yang ada konsisten atau tidak. Konsistensi data dilihat dari grafik perbandingan antara nilai rata-rata curah hujan tahunan kumulatif stasiun dengan rata-rata curah hujan tahunan kumulatif stasiun dengan rata-rata curah hujan tahunan kumulatif stasiun pembanding.

2) Uji homogenitas data hujan yang dilakukan bertujuan untuk mendapatkan data hujan yang layak untuk digunakan.

Pengolahan data untuk megukur indeks kekeringan di Kabupaten Bondowoso dilakukan dengan metode SPI (Standardized Precipitation Index). Setelah indeks kekeringan dimasing-masing wilayah diketahui, dilakukan uji kesesuaian asesmen bencana kekeringan berdasarkan perhitungan SPI dengan data kegagalan panen yang diperoleh dari dinas terkait. SPI (Standardized Precipitation Index) dengan skala watu defisit hujan 6 (enam) bulan dapat memberikan 
gambaran kondisi keparahan kekeringan yang identik dengan kekeringan pertanian. (Hayes, dkk.1999).

Pembuatan peta sebaran kekeringan dibuat setelah diperolehnya nilai indeks kekeringan SPI. Peta sebaran kekeringan dibuat untuk mengetahui sebaran kekeringan meteorologis didaerah kajian. Peta indeks kekeringan SPI dibuat dengan menggunakan program ArcGIS. Skenario perubahan iklim yang dilakukan berdasarkan Representative Concentration Pathway (RCP) yang merupakan konsentrasi gas rumah kaca (bukan emisi) yang diadopsi oleh IPCC untuk Laporan Penilaian kelima (AR5) pada tahun 2014. Ini menggantikan laporan Khusus tentang Skenario Emisi (SRES) yang diterbitkan pada tahun 2000. Gambar 2 menyajikan alur penelitian untuk menentukan tingkat kekeringan di DAS Sampean.

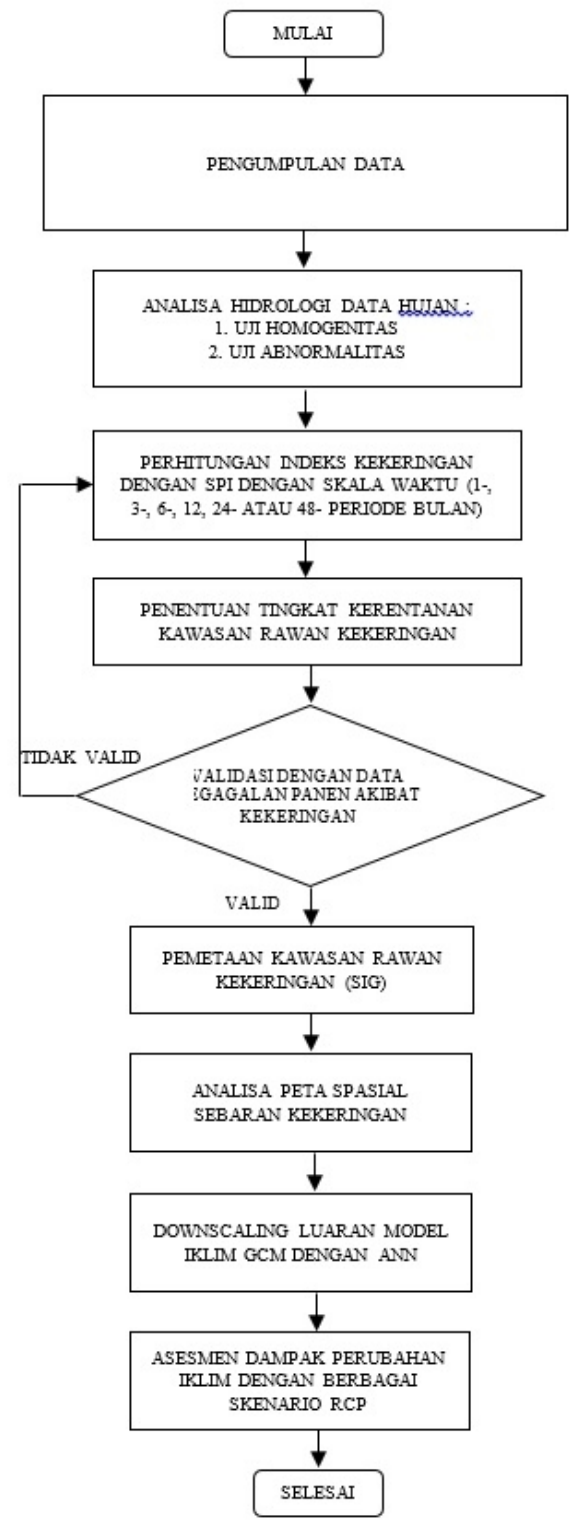

Gambar 2. Alur penelitian

\section{HASIL DAN PEMBAHASAN}

Dalam penelitian ini dilakukan perhitungan indeks kekeringan SPI (Standardized Precipitation Index) dengan skala waktu defisit hujan 6 (enam) bulan (SPI-6) menggunakan dua sumber data, yaitu data curah hujan lapangan dan data curah hujan yang diperoleh dari satelit NOAA.

Dari kedua perhitungan tersebut dapat diketahui bahwa hasil analisa indeks kekeringan dengan SPI-6 masing-masing stasiun hujan menggunakan data lapangan dengan data dari satelit NOAA memiliki pola yang sama pada masing-masing stasiun hujan.

Nilai R kuadrat atau coefficient of determination antara hasil perhitungan SPI-6 dengan data lapangan dan data dari satelit NOAA pada masing-masing stasiun hujan dapat dilihat pada tabel 1.

Tabel 2. Nilai R Kuadrat Perhitungan SPI-6 Data Lapangan dengan Data Downscalling

\begin{tabular}{cccc}
\hline No & Stasiun Hujan & $\mathrm{R}^{2}$ & Klasifikasi \\
\hline 1 & Ancar & 0,80 & Sangat Kuat \\
2 & Cermee & 0,75 & Sangat Kuat \\
3 & Jeru & 0,80 & Sangat Kuat \\
4 & Kejayan & 0,89 & Sangat Kuat \\
5 & Klabang & 0,78 & Sangat Kuat \\
6 & Kolpoh & 0,85 & Sangat Kuat \\
7 & Maesan & 0,83 & Sangat Kuat \\
8 & Maskuning Wetan & 0,83 & Sangat Kuat \\
9 & Pakisan & 0,87 & Sangat Kuat \\
10 & Pinang Pait & 0,83 & Sangat Kuat \\
11 & Prajekan & 0,78 & Sangat Kuat \\
12 & Sumber Dumpyong & 0,84 & Sangat Kuat \\
13 & Sumber Gading & 0,86 & Sangat Kuat \\
14 & Silolembu & 0,82 & Sangat Kuat \\
15 & Taal & 0,83 & Sangat Kuat \\
16 & Talep & 0,85 & Sangat Kuat \\
17 & Tlogosari & 0,78 & Sangat Kuat \\
18 & Wonosari I & 0,85 & Sangat Kuat \\
19 & Wonosari II & 0,84 & Sangat Kuat \\
20 & Wringin & 0,86 & Sangat Kuat \\
\hline
\end{tabular}

Kondisi kekeringan ektrim berdasarkan perhitungan SPI-6 pada DAS Sampean tahun 2007 digambarkan dalam Peta Sebaran Kekeringan Tahun 2007 yang tersaji pada gambar 3. 


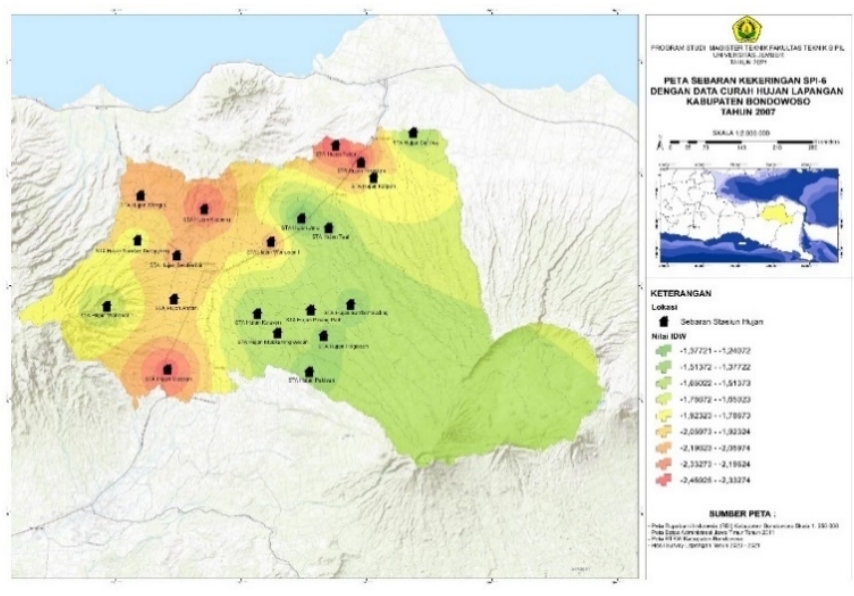

Gambar 3. Peta Sebaran Kekeringan Tahun 2007

Hasil analisa indeks kekeringan dengan SPI-6 pada DAS Sampean tahun 1988-2018 dapat dilihat pada Gambar 4.

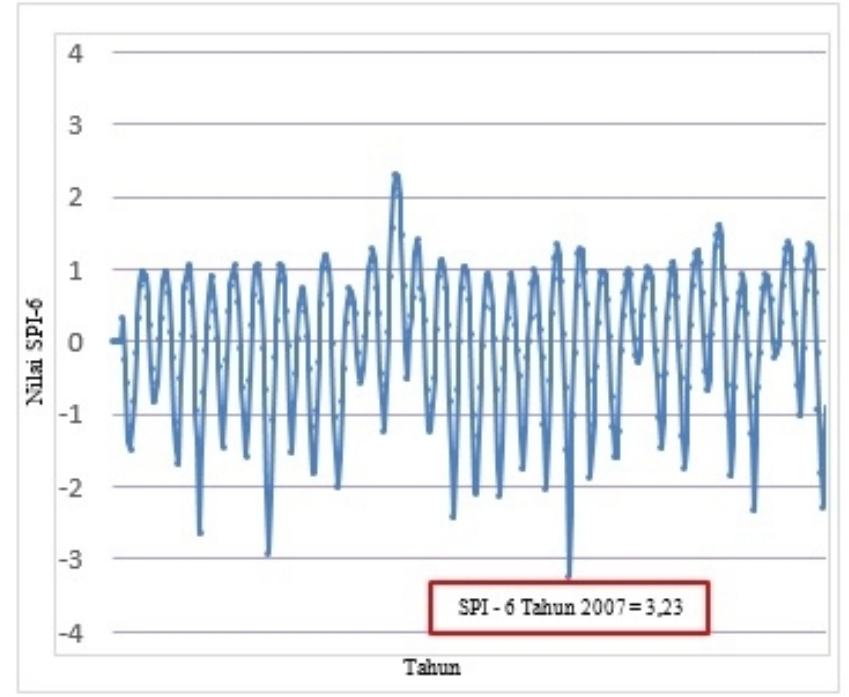

Gambar 4. Grafik Indeks kekeringan dengan SPI-6 pada DAS Sampean dengan Data Curah Hujan Rerata selama 30 Tahun (Tahun 1988-2018)

Berdasarkan gambar 4 kekeringan pada tahun 2007 dikategorikan sebagai kekeringan ekstrim atau amat sangat kering $(\mathrm{SPI}<-2)$. Untuk mengetahui kesesuaian hasil analisa dengan kondisi di lapangan, maka diperlukan pembanding berupa data luas tanaman padi yang terdampak kekeringan. Dari data yang diperoleh dari UPT LPHPPTH Tanggul-Jember, diketahui kekeringan ektrim yang terjadi di Kabupaten Bondowoso adalah pada tahun 2007 yang telah menimbulkan dampak kekeringan tanaman padi yang cukup luas yaitu 403.9 Ha. Berdasarkan kedua Analisa tersebut, dapat dinyatakan bahwa terdapat hubungan nyata antara tingkat keparahan kekeringan menggunakan SPI-6 dengan dampak kekeringan yang terjadi di lahan pertanian. Sehingga, dapat dinyatakan bahwa indeks kekeringan SPI-6 dapat digunakan untuk memonitor kekeringan pertanian.

Prediksi kekeringan akibat perubahan iklim di masa yang akan datang dilakukan berdasarkan skenario RCP 8.5. Hasil perhitungan SPI-6 RCP 8.5 dapat dilihat pada Gambar 5.

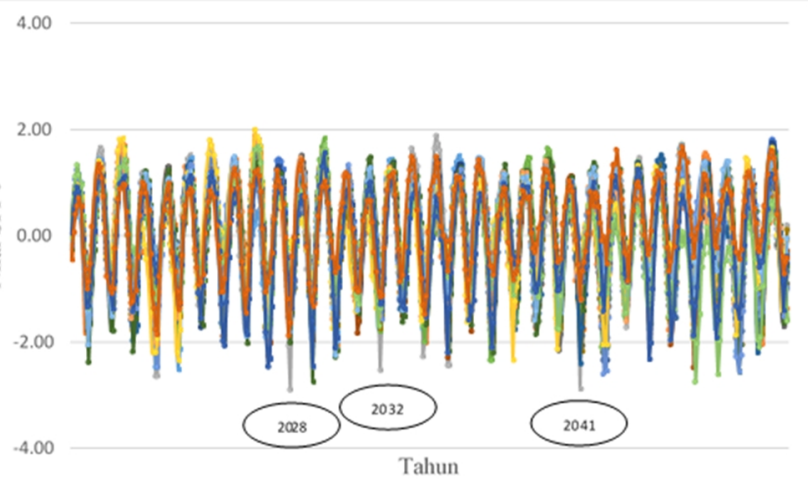

Gambar 5. Proyeksi Kekeringan selama 31 Tahun (2019-2050) Berdasarkaan Skenario RCP 8.5

Prediksi kekeringan ekstrim dengan indeks kekeringan dibawah -2 berdasarkan data RCP 8.5 diprediksi akan terjadi pada tahun 2028, 2032, dan 2041.

Berdasarkan gambar 5, dapat diketahui bahwa secara umum frekuensi kejadian kekeringan ektrim pada masing-masing stasiun hujan mengalami peningkatan dampak kekeringan seiring dengan terjadinya perubahan iklim akibat terjadinya pemanasan global. Namun Demikian, ada beberapa stasiun hujan yang menggambarkan penurunan frekuensi kejadian kekeringan ekstrim. Proyeksi iklim mempunyai tingkat ketidakpastian yang tinggi, oleh karena itu, perlu dilakukan kajian dengan berbagai model untuk melihat kecenderungannya.

\section{KESIMPULAN}

Indeks kekeringan dengan skala waktu 6 bulan (SPI-6) dapat digunakan untuk menggambarkan tingkat kekeringan sesuai dengan kondisi nyata di lapangan. Hal ini dapat ditunjukkan dengan adanya hubungan nyata atau keksesuaian antara perhitungan indeks kekeringan menggunakan SPI-6 dengan data 
luas tanaman padi yang terdampak kekeringan pada tahun 2007. Sehingga, dapat dinyatakan bahwa indeks kekeringan SPI-6 dapat digunakan untuk memonitor kekeringan pertanian.

Dampak kekeringan yang akan terjadi di masa yang akan datang diprediksi akan mengalami peningkatan seiring dengan terjadinya perubahan iklim akibat terjadinya pemanasan global.

Untuk penelitian selanjutnya, disarankan menghitung indeks kekeringan menggunakan Standardized Precipitation Index (SPI) dengan data curah hujan yang lebih panjang dan dengan jumlah stasiun hujan yang lebih lengkap sesuai dengan jumlah total stasiun hujan yang ada pada Kabupaten lokasi penelitian. Hal iini dilakukan untuk memperoleh hasil validasi yang lebih sesuai dengan kondisi nyata di lapangan.

\section{DAFTAR PUSTAKA}

[1] N. Anwar, G. Halik, and D. Edijatno, Downscaling Model Iklim sebagai Alat Bantu dalam Assessment Bencana Kekeringan terhadap Perubahan Iklim, 2014.

[2] A. Sulaeman.. Pengaruh Upah Dan Pengalaman Kerja terhadap Produktivitas Karyawan Kerajinan Ukiran Kabupaten Subang. Trikonomika, vol. 13, no. 1, pp. 91100, 2014.

[3] M. J. Hayes, M. D. Svoboda, D. A. Wilhite, and O. V. Vanyarkho, Monitoring the 1996 Drought Using the Standardized Precipitation Index. Bulletin of the American Meteorological Society, vol. 80, no. 3, pp. 429438, 1999.

[4] W. A. Kusumawati, C. Mohammad, and S. Sigit, Simulasi Aquacrop Untuk Memproyeksikan Produktivitas Padi Berdasarkan Skenario Perubahan Iklim Representative Concentration Pathways (Rcp) 4.5 Di Kabupaten Bengkulu Utara, Jurnal Penelitian Pengelolaan Sumberdaya Alam Dan Lingkungan, vol. 9 no. 2, pp. 133-142, 2020.

[5] F. I. Nurrahman, and A. Pamungkas, Identifikasi Sebaran Daerah Rawan Bahaya Kekeringan Meteorologi di Kabupaten Lamongan. Jurnal Teknik Pomits, vol. 2, no. 2, pp. 83-86, 2013

[6] H. Saidah, M. B. Budianto, and L. Hanifah, Analisa Indeks dan Sebaran Kekeringan Menggunakan Metode Standardized Precipitation Index (SPI) dan Geographical Information System (GIS) untuk Pulau Lombok, Jurnal Spektran, vol. 5, no. 2, 2017

[7] I. K. Sari, L.M. Limantara, and D. Priyantoro, Analisa Ketersediaan dan Kebutuhan Air pada DAS Sampean. Jurnal Teknik Pengairan, vol. 2, no. 1, pp. 29-41, 2012.
[8] S. Afdeni, S. Sutikno, Y. L. H. Analisis Indeks Kekeringan Meteorologis Lahan Gambut Di Pulau Bengkalis-2, 2017

[9] M. Teja, D. Harisuseno, and D. Chandrasasi, Perbandingan Metode Standardized Precipitation Index (Spi) Dan Thornthwaite Mather Dalam Menentukan Indeks Kekeringan Pada Das Rondoningu Kabupaten Probolinggo, 2017.

[10] Wigena, A. Hamim, A. Djuraidah, S. S. pp. 259-525-1SM.pdf, 2017. 